Proceeding Paper

\title{
Carbon Stock in Forest Stands of Ukrainian Eastern Forest- Steppe: Forest Monitoring Data ${ }^{\dagger}$
}

\author{
Volodymyr Pasternak, Tetiana Pyvovar and Volodymyr Yarotsky*
}

Citation: Pasternak, V.; Pyvovar, T.; Yarotsky, V. Carbon Stock in Forest Stands of Ukrainian Eastern ForestSteppe: Forest Monitoring Data. Environ. Sci. Proc. 2021, 3, 29. https://doi.org/10.3390/IECF202007964

Academic Editors: Angela Lo Monaco, Cate Macinnis-Ng and Om P. Rajora

Published: 12 November 2020

Publisher's Note: MDPI stays neutral with regard to jurisdictional claims in published maps and institutional affiliations.

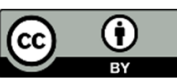

Copyright: $₫ 2020$ by the authors. Licensee MDPI, Basel, Switzerland. This article is an open access article distributed under the terms and conditions of the Creative Commons Attribution (CC BY) license (http://creativecommons.org/licenses/by/4.0/).

\author{
Ukrainian Research Institute of Forestry and Forest Melioration Named after G.M. Vysotskiy, \\ Kharkiv 61024, Ukraine; Pasternak65@ukr.net (V.P.); pyvovartatiana@gmail.com (T.P.) \\ * Correspondence: suerlay@ukr.net; Tel.: +380-57-707-80-44 \\ † Presented at the 1st International Electronic Conference on Forests - Forests for a Better Future: Sustainability, \\ Innovation, Interdisciplinarity, 15-30 November 2020; Available online: https://iecf2020.sciforum.net.
}

\begin{abstract}
In Ukraine, carbon stocks in forests are assessed by the gain-loss method since the national forest inventory is under development now. For the evaluation of main pools of oak and pine forest stands, typical for the Forest-steppe of Ukraine, the stock-difference method was used for the data of repeated observations on 18 intensive forest monitoring plots. The average carbon stock in the phytomass was $94.1 \pm 19.8 \mathrm{tC} \cdot \mathrm{ha}^{-1}$ and $93.4 \pm 12.8 \mathrm{tC} \cdot \mathrm{ha}^{-1}$, while in the deadwood, it was $8.8 \pm 7.3$ $\mathrm{tC} \cdot \mathrm{ha}^{-1}$ and $5.3 \pm 4.3 \mathrm{tC} \cdot \mathrm{ha}^{-1}$ for oak and pine forest stands, respectively. In terms of age classes, pine stands, due to their higher productivity, in general, had a higher carbon (C) stock in phytomass compared to oak. C stock changes in trees phytomass were the highest in younger stands, and they decreased with age, while in deadwood, they increased. At age 81-100 years, oak forest stands had higher carbon storage capacity than pine (total stock in main pools (phytomass, mortmass, and soils (30-cm layer)) was $191.7 \mathrm{tC} \cdot \mathrm{ha}^{-1}$ for oak and $175.4 \mathrm{tC} \cdot \mathrm{ha}^{-1}$ for pine stands). Trees phytomass carbon prevailed among other pools (50.3\% in oak forests and $57.6 \%$ in pine).
\end{abstract}

Keywords: carbon pools; phytomass; dead wood; carbon stock changes; oak stands; pine stands; age classes

\section{Introduction}

In many countries, for greenhouse gases (GHG) emissions estimates, especially carbon, in the forest sub-sector, national forest inventory (sample-based) (NFI) data are used [1]. In Ukraine, the NFI system is under development now, so the source of data for GHG reporting is the data of stand-wise forest inventory [2,3]. The methodology to calculate carbon stocks and test on forest monitoring plots is important for the development of NFI in Ukraine.

\section{Materials and Methods}

The study was held in the Eastern part of Ukraine (Kharkiv and Sumy regions), in the ecological zone of temperate forests (Forest-steppe zone) [4]. The data were collected at 18 intensive forest monitoring plots with the fixed area at two consequent observations in a 4-year interval. These monitoring plots are located at Scots pine (4 plots) (Pinus sylvestris L.) and English oak (14 plots) (Quercus robur L.) forest stands, which are typical Forest-steppe zones in the eastern part of Ukraine. Studied oak stands are represented mainly by natural coppice stands with an admixture of other deciduous species (Fraxinus excelsior L., Acer platanoides L., Tilia cordata Mill., etc.) on dark gray forest soils. Pine stands are artificial monodominant Scots pine forests on sandy sod-podsolic soils. The age of these stands varied from 44 to 144 years old; the average age of pine stands was 68 years, while that of oak was 99 years. 
All trees with diameter at breast height $\mathrm{DBH} \geq 12 \mathrm{~cm}$ (living and dead) on these monitoring plots were mapped, measured, and their sanitary condition was estimated. The litterfall type and thickness, as well as soil type, were determined. All dead logs with a diameter of $\geq 7 \mathrm{~cm}$ and stumps with a diameter of $>14 \mathrm{~cm}$ were measured; their decomposition stage was evaluated.

Carbon (C) stock was evaluated for two observations at trees phytomass and deadwood mortmass (dead trees, dead logs, and stumps) by Intergovernmental Panel on Climate Change (IPCC) formulas [1], taking into account the basic wood density of trees species [5] and decomposition stage of deadwood [6,7]. For the estimation of carbon dynamics on studied monitoring plots by carbon pools, the stock-difference method was used [1].

Data were analyzed for pine and oak forest stands, in general and by 20-year age classes, as age influences the process of tree growth and carbon accumulation [8]. For the comprehensive evaluation of main carbon pools at plots level, the additional data on average soil carbon in 30-cm soil level and litter carbon stocks from [9] for the region of study (Forest-steppe) and types of forest stands were used.

\section{Results}

The average carbon stock in trees phytomass was $94.1 \pm 19.8 \mathrm{tC} \cdot \mathrm{ha}^{-1}$ at the studied oak stands and $93.4 \pm 12.8 \mathrm{tC} \cdot \mathrm{ha}^{-1}$ at pine stands (Table 1 ). In all types of stands, the phytomass $C$ stocks increased with age; just at one plot at the oak stand (age 61-80 years), it decreased due to the mortality of significant trees caused by biotic damage. The average deadwood C stocks at the studied oak stands were $8.8 \pm 7.3 \mathrm{tC} \cdot \mathrm{ha}^{-1}$, while in the pine stands were $5.3 \pm 4.3 \mathrm{tC} \cdot \mathrm{ha}^{-1}$.

Table 1. Carbon stocks $\left(\mathrm{t} \mathrm{ha}^{-1}\right)$ and dynamics $\left(\mathrm{t} \mathrm{ha}^{-1} \mathrm{year}^{-1}\right)$ in phytomass and mortmass of the studied oak and pine stands.

\begin{tabular}{ccccc}
\hline $\begin{array}{c}\text { Forest Type and } \\
\text { Age Class }\end{array}$ & $\begin{array}{c}\text { C Stock in Trees } \\
\text { Phytomass }\end{array}$ & $\begin{array}{c}\text { C Stock in Deadwood } \\
\text { Mortmass }\end{array}$ & $\begin{array}{c}\text { Average C Change in } \\
\text { Trees Phytomass }\end{array}$ & $\begin{array}{c}\text { Average C Change in } \\
\text { Deadwood Mortmass }\end{array}$ \\
\hline Oak 41-60 years & 91.1 & 5.0 & 2.7 & 1.1 \\
Oak 61-80 years & 60.2 & 11.9 & -2.0 & 0.3 \\
Oak 81-100 years & $96.5 \pm 23.0$ & $4.4 \pm 4.0$ & 1.6 & 0.1 \\
Oak 101-120 years & $98.5 \pm 17.4$ & $8.6 \pm 6.8$ & -0.3 & 1.8 \\
Oak > 120 years & $97.6 \pm 10.5$ & $15.7 \pm 7.4$ & -1.9 & 0.5 \\
Average Oak & $94.1 \pm 19.8$ & $8.8 \pm 7.3$ & 0.2 & 0.6 \\
Pine 41-60 & 71.9 & 1.0 & 2.9 & 0 \\
Pine 61-80 & $100.3 \pm 4.4$ & $4.2 \pm 2.4$ & 1.4 & 0.8 \\
Pine 81-100 & 101.1 & 11.8 & -0.9 & 2.7 \\
Average Pine & $93.4 \pm 12.8$ & $5.3 \pm 4.3$ & 1.2 & 1.1 \\
\hline
\end{tabular}

Data showed (see Table 1) that both pine and oak stands at age 41-60 years had the highest $C$ change due to their intensive growth. The oldest stands had negative trees phytomass $C$ change and positive deadwood $C$ change due to slow growth and increased mortality.

According to the combined calculation at studied forest stands obtained on the basis of our observations on $C$ stock in stands and deadwood and data from [9] on C stock in soils and litter at age class 81-100 in oak forest, the total carbon stock in main carbon pools was $191.7 \mathrm{t} \mathrm{C} \mathrm{ha-1}^{-1}$ (phytomass-96.5, mortmass-4.4, soil-88.0, litter-2.8 $\mathrm{t} \mathrm{Cha}^{-1}$ ) and at pine stands was $175.4 \mathrm{t} \mathrm{C} \mathrm{ha-1} \mathrm{(phytomass-101.1,} \mathrm{mortmass-11.8,} \mathrm{soil-50.9,} \mathrm{litter-11.6} \mathrm{t} \mathrm{C} \mathrm{ha-1).}$

\section{Discussion}

Results showed that the average carbon stocks in trees phytomass and mortmass of the studied oak stands were higher than in pine stands, which was associated with a difference in age structure (oak stands were older than pine stands). Our results were lower 
than the average values calculated for modal oak and pine stands (104 and $101.3 \mathrm{t} \mathrm{C} \mathrm{ha}^{-1}$, respectively) for the Forest-steppe zone of Ukraine at the same age, according to [2]. For these calculations, the gain-loss method was used.

The results showed that deadwood $C$ stock at oak stands was higher than in pine stands due to higher mortality rates and longer decomposition period of the oak deadwood.

So, our data proved that, in general, at age 81-100 years, oak stands have higher carbon storage capacity than pine stands. Among other pools, trees phytomass plays the most significant role in C sequestration $(50.3 \%$ and $57.6 \%$ of total carbon stock in oak and pine stands, respectively); the second important pool is forest soil (45.9 and $29.0 \%$, oak and pine stands, respectively), while the deadwood and litter pool are the smallest (3.8\% and $13.3 \%$, oak and pine stands, respectively).

However, these results are preliminary and just show general trends and illustrate the methods used. Of course, implementation of NFI and soil monitoring at the country level will allow obtaining more detailed estimates in these carbon pools values for different forest types and age groups, and just after two repeated NFI observations, it will be possible to obtain modern data on carbon budget in the forests of Ukraine.

Author Contributions: V.P. - conceptualization, methodology, formal analysis, data analysis, validation, investigation, writing-review and editing; T.P.-methodology, writing-original draft preparation; V.Y. - investigation (fieldwork), data analysis. All authors have read and agreed to the published version of the manuscript.

Funding: This research received no external funding.

Conflicts of Interest: The authors declare no conflict of interest.

\section{References}

1. Hiraishi, T.; Krug, T.; Tanabe, K.; Srivastava, N.; Baasansuren, J.; Fukuda, M.; Troxler, T.G. (Eds.) Revised Supplementary Methods and Good Practice Guidance Arising from the Kyoto Protocol. IPCC 2014. IPCC: Geneva, Switzerland. Available online: https://www.ipcc-nggip.iges.or.jp/public/gpglulucf/gpglulucf.html (accessed on 29 September 2020).

2. Shvidenko, A.; Lakyda, P.; Schepaschenko, D.; Vasylyshyn, R.; Marchuk, Y. Carbon, Climate, and Land-Use in Ukraine: Forest Sector: A Monograph; FOP Gavrishenko, V.M.: Korsun-Shevchenkivskyi, Ukraine, 2014; 283p.

3. Buksha, I.F.; Butrim, O.V.; Pasternak, V.P. Inventory of Greenhouse Gases in the Land Use and Forestry Sectors: A Monograph; KhNAU: Kharkiv, Ukraine, 2008; 232p. (In Ukrainian)

4. Didukh, Y.P.; Fitsailo, T.V.; Korotchenko, I.A.; Iakushenko, D.M.; Pashkevich, N.A. Biotopes of Forest and Forest-Steppe Zones of Ukraine; LLC MACROS: Kyiv, Ukraine, 2011; 288p. (In Ukrainian)

5. Lakida, P.I.; Vasylyshyn, R.; Lashenko, A.; Terentiev, A. Standards of Evaluation of Components of Aboveground Trees Biomass of Trees of the Main Forest-Forming Species of Ukraine; ECO-Inform: Kyiv, Ukraine, 2011; 192p.

6. Avramchuk, O.O.; Bilous, A.M.; Golyaka, D.M.; Ischenko, M.B.; Kyslytsya, P.S. Evaluation of logs in pine plantations of Kyiv Polissya. Proc. Natl. Univ. Life Environ. Sci. Ukr. For. Decor. Gard. 2015, 219, 11-18. (In Ukrainian)

7. Yarotskiy, V.Y.; Pasternak, V.P.; Nazarenko, V.V. Deadwood in the oak forests of the Left Bank Forest steppe of Ukraine. Folia For. Pol. Ser. A For. 2019, 61, 247-254, doi:10.2478/ffp-2019-0024.

8. Pregitzer, K.S.; Euskirchen, E.S. Carbon cycling and storage in world forests: Biome patterns related to forest age. Glob. Chang. Biol. 2004, 10, 2052-2077, doi:10.1111/j.1365-2486.2004.00866.x.

9. Buksha, I.F.; Raspopina, S.P.; Pasternak, V.P. Assessment of organic carbon stock in soil and litterfall in forests of Ukraine. For. For. Melior. 2012, 120, 106-112. (In Ukrainian) 